\title{
EFFECT OF AGREEMENT TO FINANCE AGRICULTURAL MARKETING ON BANK'S LIABILITY TO PAYEE OF CHECK
}

IT WAS formerly held in some jurisdictions that an unaccepted check operated as a pro tanto assignment of the funds on deposit, the payee thereof having a right of action against a bank which refused payment with adequate funds of the drawer on hand. ${ }^{1}$ But the Negotiable Instruments Law has abrogated this rule, ${ }^{2}$ and it is now generally said that the payee of an unaccepted check has no rights against the drawee bank. ${ }^{3}$ Nevertheless, payees of checks have repeatedly recovered against drawee banks where the circumstances were substantially as follows: A dealer engaged in purchasing livestock, poultry, or grain from farmers and reselling the commodities to commission houses lacks funds with which to conduct his business. He therefore enters into an agreement ${ }^{4}$ with a bank, whereby the bank promises to honor any checks he draws upon it in paying for purchases made in the course of business, and he either agrees to deposit with it the proceeds derived from reselling the goods involved, or to deliver to the bank a draft therefor on his consignee, sometimes to be accompanied by a bill of lading. Ordinarily the checks are to be paid after the bank has received the resale proceeds or draft, although occasionally the bank agrees to pay them on presentation whether or not it has received either. Pursuant to this agreement the dealer makes purchases, paying by check, on which he sometimes indicates the merchandise involved, sells the goods, and either deposits the proceeds or delivers a draft on the consignee. At some point in the history of this arrangement, a payee farmer or ranchman presents a check given him by the dealer in payment for the goods shipped, or for a part thereof, but the bank, although aware of the origin of the check, claims the right to apply whatever proceeds it has on hand to outstanding debts due it from

1. Note, L. R. A. 1916 C 164, 169; Branwar, NegothidLE Instruase:its LAW (5th ed. 1932) 1073; 5 MíchIE, Banks and Banking (Perm. ed. 1932) 366; see 2 MIORSE, Banks and Banking (6th ed. 192S) \$491 et seq.

2. Section 189 provides: "A check of itself does not operate as an assignment of any part of the funds to the credit of the drawer with the bank, and the bank is not liable to the holder, unless and until it accepts or certifies the chect:"

3. South Carolina Nat. Bank v. McCandless, 44 F. (2d) 111 (C. C. A. 4th, 1930); Brantley v. Collie, 205 N. C. 229, 171 S.E. SS (1933); Bradx, Bars Cracks (2d ed. 1926) 17; 5 MIICEIE, op. cit. stipra note 1, 373-377; see Aigler, Rights of Holder of Bill of Exchange Against the Drawee (1925) $3 S$ HARv. L. REv. 857.

4. Occasionally the agreement is implied by virtue of a continued course of dealing between the bank and its customer. Pierceville State Bank v. Gray County Banls, 113 Kan. 352, 214 Pac. 78S (1923) ; Singer v. Citizens' Bank of Headrick, 79 Otda. 257, 193 Pac. 41 (1920); Webster v. First State Bank of Peever, 46 S. D. 460,193 N. W. 675 (1923), 50 S. D. 159, 208 N. W. 774 (1926). 
the dealer, asserts that the dealer's credit balance is inadequate, and refuses payment. Thereupon it is sued by the payee for the face value of the check.

The courts have justified recovery in such situations by several theories. Most frequently relief has been granted on the ground that the payee is a third party beneficiary of the agreement described. ${ }^{B}$ This reasoning should require a preliminary analysis of the bargain between the dealer and the bank in order to determine whether the bank has broken its promise. The bank may have promised to honor the dealer's checks only after it has received the resale proceeds of the goods for which those particular checks were given. Such an agreement might be one to pay the dealer's subsequent overdrafts arising out of the particular transaction, the consideration for the future credit extension being the dealer's promise to deposit the proceeds from future resales $^{7}$ and in some cases to pay interest ${ }^{8}$ or it might be one merely to

5. For cases where recovery was allowed, see notes $6,17,22,39$, infra; if. Union Stockyards Bank v. Gillespie, 137 U. S. 411 (1890); Steere v. Stockyards National Bank, 113 Tex. 387, 256 S. W. 586 (1923), 258 S. W. 1042 (1924). Contra: Andrew v. Waterville Savings Bank, 205 Iowa 888, 219 N. W. 53 (1928); cf. Brantley v. Collic, 205 N. C. 229,171 S. E. 88 (1933); In re Security Savings Bank, 211 N. W. 233 (Iowa 1927) ; Bank of Magazine v. Friddle, 179 Ark. 53, 14 S. W. (2d) 238 (1929); Citizens' Bank of Gans v. Mabray, 90 Okla. 63, 215 Pac. 1067 (1923); Ward Commission Co. v. Sioux Falls National Bank, 199 Iowa 829, 202 N.W. 829 (1925) (compare with Gillespic case, stipra).

6. Chanute National Bank v. Crowell, 6 Kan. App. 533, 51 Pac. 575 (1897); Bank of Garnett v. Cramer, 7 Kan. App. 461, 53 Pac. 534 (1898); Ballard v. Home National Bank of Arkansas City, 91 Kan. 91, 136 Pac. 935 (1913); Saylors v. State Bank of Allen, $99 \mathrm{Kan} .515$, $100 \mathrm{Kan} .64,163 \mathrm{Pac} .454$ (1917); Goeken v. Bank of Palmer, 100 Kan. 177, 163 Pac. 636 (1917), 104 Kan. 370, 179 Pac. 321 (1919); Humpert v. Citizens' State Bank of Talmadge, 122 Kan. 101, 250 Pac. 1077 (1926); Singer v. Citizens' Bank of Headrick, 79 Okla. 267, 193 Pac. 41 (1920); Webster v. First State Bank of Peever, 46 S. D. 460, 193 N. W. 675. (1923), 50 S. D. 159, 208 N. W. 774 (1926) ; Pascoe v. Franklin County State Bank, 217 Iowa 205, 251 N. W. 63 (1933) semble; Scoby v. Bird State Bank, 112 Kan. 135, 211 Pac. 110 (1922) semble; see Northcraft v. Home State Bank, 120 Kan. 572, 575, 245 Pac. 114, 115 '(1926); of. Manget v. National City Bank, 168 Ga. 876, 149 S. E. 213 (1929) ("Where the promise of benefit to the third person creates a trust in his favor, he may enforce, the trust in a court of equity"). See 2 Wriliston, Contracts (Rev. ed. 1936) $\$ 389$.

Usually the plaintiff is unaware of the agreement and the courts generally hold that he need not have knowledge thereof to recover as a third party beneficiary. See cases cited supra. But cf. First Nat. Bank of Chicago v. Pettit \& Smith, 41 I1l. 492 (1866); Nelson v. First National Bank of Chicago, 48 III. 36 (1868) ; Citizens' Bank of Gans v. Mabray, 90 Okla. 63, 215 Pac. 1067 (1923); Brown v. Mutual Trust Co., 267 Pa. 523, 110 Atl. 155 (1920).

7. The receipt of a deposit was held sufficient consideration for a promise to extend a $\$ 10,000$ line of credit in Farabee-Treadwell Co. v. Union \& Planters' Bank \& Trust Co., 135 Tenn. 208, 186 S. W. 92 (1916) ; see Merchants Bank \& Trust Co. of Canada v. Sims, 122 Wash. 106, 114, 209 Pac. 1113, 1116 (1902) (that business to be transacted with appellant bank constitutes consideration). But $c f$. Swindell \& Co. v. First National Bank, 121 Ga. 714, 49 S. E..673 (1905). 
honor the checks if a sufficient balance remained after all the bank's matured claims against the dealer had been satisfied. ${ }^{8}$ In either case, the bank's refusal to honor the plaintiff's check before receipt of the proceeds, or to honor checks arising out of other transactions, would not constitute a breach of its contract; nor in the latter case, would a breach result from a refusal to honor checks even after the receipt of the proceeds provided that the dealer's credit balance was inadequate. On the other hand, the bank's promise may be one to honor the dealer's overdrafts from the inception of the agreement in return for the dealer's promise to deposit the resale proceeds. Two constructions would then be possible as to the period during which credit vas to be extended. Such a promise might be interpreted as one to pay overdrafts during each interval between the purchase of commodities in a particular transaction and the receipt of the resale proceeds therefrom. In that case, the refusal to honor checks presented after the receipt of proceeds from one shipment and before the inception of another transaction would not constitute a breach unless the dealer's credit balance were sufficient Or the promise might be one to pay all overdrafts made in the ordinary course of business for a reasonable time regardless of whether the checks were presented before or after the receipt of the resale proceeds from any particular transaction. The refusal to honor any business check would then be a breach of the bank's promise. It is sometimes difficult to determine from the reported decisions the precise terms of the agreement involved; ${ }^{10}$ perhaps the parties themselves may have failed to make this explicit; nor is the practice so general that business usage points unmistakably to one interpretation or another. Generally, however, the courts seem to have concluded that an overdraft agreement arose whereby the bank was to pay the dealer's checks and the dealer to deposit the resale proceeds, the bank being bound

8. The opinions do not ordinarily disclose the amount of interest, if any, to be paid. However, $S$ per cent interest was provided for in Saylors v. State Bank of Allen, 99 Kan. 515, 163 Pac. 454 (1917), and the "regular rate" in Bank of Garnett v. Cramer, $7 \mathrm{Kan}$. App. 461, 53 Pac. 534 (1898). In the majority of the cases the bank's extension of credit was apparently unsecured. But in the Bank of Garnelt case, sipra, the bank received a bond, signed by the dealer and two sureties, guaranteeing that the dealer's overdrafts would be repaid on demand. Cf. Gillen v. Wakefield State Bank, 246 ALich. 158,224 N. W. 761 (1929) (agreements in writing in the form of signed notes with no sum fixed endorsed by dealer to bank to cover overdrafts); Dolan v. Danbury State Bank, 207 Iowa 597, 223 N. W. 400 (1929) (attempted overdraft agreement limited to $\$ 1500$, bank being secured by three $\$ 500$ notes).

9. In this view of the bargain, the only deviation from the conventional bank-depositor relationship resulting from the agreement is that the bank understonds that the dealer will issue checks before he has deposited the funds to meet them.

10. The bank's agreement may also be to apply the proceeds of each shipment to those checks given for the particular merchandise comprising the shipment. If so, the payee might recover on the ground that a deposit for a specific purpose arose and the third party beneficiary doctrine is unnecessary. See page 487 infra. 
regardless of whether those proceeds proved sufficient, so that the bank breached its promise when it dishonored the plaintiff's check.11

But even if a breach has occurred, there are doctrinal objections to allowing the plaintiff relief as a third party beneficiary. ${ }^{12}$ Although it is uniformly recognized that a bank promises all its checking account depositors to pay their checks to the amount of their deposits, ${ }^{13}$ payees suing as third party beneficiaries of this promise have been denied recovery primarily on the ground that a contrary result would subject banks to double liability and so nulliry the effect of the rule that a check is not an assignment. ${ }^{14}$ Recognizing this, the courts have attempted to distinguish the cases under discussion on the theory that these actions were not based simply on the "check alone" or the usual promise of a bank to a drawer, but upon the "entire transaction" between them. ${ }^{15}$ The distinction hardly seems persuasive. Despite the "entire transaction," the promise of the bank to the drawer remains essentially the same type of promise that exists in the conventional bank-depositor relation-

11. In Saylors v. State Bank of Allen, 99 Kan. 515, 100 Kan. 64, 163 Pac. 454 (1917), whether the bank had promised to pay the dealer's checks only up to the amount of the resale proceeds or had agreed to pay the dealer's overdrafts was held to be a question for the jury. Cf. Northcraft v. Home State Bank, 120 Kan. 572, 575, 245 Pac. 114, 115 (1926).

12. Occasionally the banks have unsuccessfully attempted to defend on the ground that the alleged overdraft agreement was ultra vires and void. Saylors v. State Bank: of Allen, 99 Kan. 515, 100 Kan. 64, 163 Pac. 454 (1917) (admitting overdraft agreements disfavored, but declaring them legal); Humpert v. Citizens' State Bank of Talmadge, $122 \mathrm{Kan} .101,250 \mathrm{Pac} .1077$ (1926) (defense unavailable when "arrangement .. . so far . . . carried out"); see Bradx, Bank Checks (2d ed. 1926) 411, note 11. Contra: S. R. \& P. Import Co. v. American Union Bank, 122 Misc. 798, 204 N. Y. Supp. 755 (Sup. Ct., 1924) (overdraft agreement contrary to public policy and void).

13. 5 MicnIE, op. cit. supra note $1,375,423$, note $46 ; 2$ Morse, op. cit. sutpra note $1, \S 458$. For a comprehensive analysis of the agreement ordinarily entered into by a bank and a depositor at the inception of a checking account, see Moore, Sussman \& Brand, Legal and Institutional Methods Applied to Orders to Stop Payment of Checks, I: Legal Methods (1933) 42 YaLE L. J. 817.

14. If recovery is allowed, the bank is of course liable to suit both by the payee and drawer. Cf. Dolan v. Danbury State Bank, 207 Iowa 597, 223 N. W. 400 (1929). This possibility was held to bar recovery on the third party beneficiary theory prior to the adoption of the Negotiable Instruments Law. Cincinnati, Hamilton \& Dayton R. R. v. Bank, 54 Ohio St. 60, 42 N.E. 700 (1896); Carr v. National Security Bank, 107 Mass. 45 (1871) (saying also that there was no privity of contract); Bank of the Republic v. Millard, 10 Wall. 152 (U. S. 1869) semble. Today, recognition of payecs as beneficiaries would similarly avoid the purpose of Section 189 of the Negotiable Instruments Law, supra note 2. That the purpose of that section is to safeguard banks against the risk of double liability, see Central Trust Co. v. Bank of Mullens, $108 \mathrm{~W}$. Va. 12, 19, 150 S. E. 137, 139 (1929) ; Elgin v. Gross-Kelly \& Co., 20 N. M. 450, 464, 150 Pac. 922, 925 (1915) ; Hove v. Stanhope State Bank, 138 Iowa 39, 43, 115 N. W. 476, 487 (1908); 5 Micrie, op. cit. supra note $1,371$.

15. See, e.g., Ballard v. Home National Bank of Arkansas City, 91 Kan. 91, 96, 136 Pac. 935, 936 (1913). 
ship, namely, one to pay his checks. ${ }^{10}$ No greater intent to benefit the payee exists in one case than in the other, and to allow recovery in the instant type of situation results in double. liability which is just as much a nullification of the Negotiable Instruments Law as it would be in the ordinary case.

A second theory on which recovery has been allowed is that the deposit of the proceeds was special or specific rather than general. ${ }^{17}$ While a survey of the cases reveals no single clearly defined test, a deposit is usually said to be special or specific if the bank promises that it will be used only for a designated purpose.18 In the situation under consideration, if the bank promises that the resale proceeds from a particular transaction will be used only to pay the checks given in that transaction, including the payee's, thus satisfying the foregoing definition of special or specific deposits, there is substantial authority that the payee is entitled to recover. ${ }^{10}$ But such a construction would seem improper in the usual case. First, there is a presumption in favor of a general deposit. ${ }^{20}$ But more important, the mere fact that the agreement contemplates a continuing relationship suggests that the parties intended the bank to be free to apply deposits to previous obligations of the

16. Cf. Brown v. Mutual Trust Co., 267 Pa. 523, 110 Atl. 155 (1920); First Nat Bank of Chicago v. Pettit \& Smith, 41 IIl. 492 (1S66); see Continental Bank and Trust Co. v. Hartman, 129 S. W. 179, 180 (Tex 1910).

17. Ballard v. Home National Bank of Arkansas City, 91 Kan. 91, 136 Pac. 935 (1913); Mroravek v. First National Bank of Jewell City, 119 Kan. 84, 237 Pac. 921 (1925); MForton v. Woolery, 48 N. D. 1132, 189 N. W. 232 (1922); Payne Bros. v. Burnett, 151 Tenn. 496, 269 S. W. 27 (1925) semble (holding funds "impressed with a trust"); see Wilson v. Dawson, 52 Ind. 513, 515 (1876); cf. Ifanget v. National City Bank, 168 Ga. 876, 883, 149 S. E. 213, 217 (1929); Houck v. Bank of Newport, 150 Ore. 295, 303, 43 P. (2d) 179, 182 (1935); German National Banls v. Grinstead, 26 Ky. L. Rep. 674, 52 S. W. 951 (1S99) ; Parkersburg Mill Co. v. Farmers' and Traders' National Bank, 26 Ky. L. Rep. 964, 82 S. W. 1003 (1904). Contra: Andrew v. Waterville Savings Bank, 205 Iowa $8 \$ 8,219$ N.W. 53 (192S); of. In re Security Savings Bank of Perry, 211 N.W. 233 (Iowa 1927).

18. Straus v. Tradesmen's National Bank, 122 N. Y. 379, 25 N..E. 372 (1590); Corporation Commission of North Carolina v. Merchants' Bank and Trust Co., 193 N. C. 696, 138 S. E. 22 (1927) ; Decatur Creamery v. West Side Trust and Savings Banl; 213 III. App. 220 (1919); see Notes (1924) 24 A. L. R. 1111, (1925) 39 A.L.R. 113S, (1933) S6 A. L. R. 375; 5 MIICEIE, op. cit. stpra note 1, 635 et seq.; 1 MLorse, op. cit. supra note $1, \$ 185 ; 2$ Mínse, op. cit. supre note $1, \$ 567$.

The courts frequently use the terms special and specific interchangeably. That there is a distinction, see Collins v. Miorgan County Nat. Bank, 226.Ala. 376, 147 So. 161 (1933) ; Corporation Commission of North Carolina v. Merchants' Bank and Trust Co., 193 NT. C. 696, 699, 13S S. E. 22, 24 (1927); see Comment (1935) S So. Carrr. I. Rer. 122. Strictly speaking, a special deposit arises only when the identical thing deposited is to be returned to the depositor. See 1 MIORSE, op. cit. supra note $1, \S 183 ; 5$ 3IrCEIE, $o p$. cit. supra note 1, 626, note 10; id. (Supp. 1936) 626, note 10. A specific deposit might be more accurately described as a general deposit for a specific purpose.

19. See cases cited note 18, stipra.

20. 1 MIORSE, op. cit. supra note $1, \S 186 ; 5$ IÍrCnIE, op. cit. sipra note 1, 25. 
dealer arising from his business operations. ${ }^{21}$ And force is lent to the suggestion when it is considered that if the dealer made several shipments at approximately the same time, giving rise to several deposits, the bank might have considerable difficulty in determining which deposit was to be applied to any particular check presented for payment. Accordingly, even if the resale proceeds are to be deposited before the checks are to be paid, it is probably more accurate to describe the bank's promise as one to honor the checks on condition that the proceeds are deposited, not as one to devote those particular proceeds to the payment of particular checks.

A third theory on which recovery has been allowed is that the bank, aware of the dealer's method of operation, has knowingly acquired money belonging to the payee and so must pay it over.to him on demand. ${ }^{22}$ The basis for this conclusion is the rule that when a check is given in payment in a cash sale, title to the goods remains in the seller until the check is paid,.notwithstanding delivery of the goods to the buyer, unless there is affirmative evidence that the seller intended to accept the check as absolute payment; and that therefore if the vendor does not waive the condition of cash payment by failing to act with reasonable promptness, he may recover the goods or the proceeds thereof from subsequent purchasers, in many cases even though they are innocent, ${ }^{23}$ or from creditors of the vendee. ${ }^{24}$ It should be observed that this

21. For a detailed discussion of the character of the deposit in these cases, sce Andrew v. Waterville Savings Bank, 205 Iowa 888, 219 N. W. 53 (1928).

Where the circumstances are otherwise analogous, but the arrangement only temporary, there is more justification for holding the deposit to be special or specific. See First National Bank v. Barger, 115 S. W. 726 (Ky. 1909), and Falls City State Bank v. Wehrli, 68 Neb. 75, 93 N.W. 994 (1903), both of which arose in jurisdictions then recognizing a check as a pro tanto assignment.

22. Johnson-Brinkman Commission Co. v. Central Bank of Kansas City, 116 Mo. 558, 22 S. W. 813 (1893) ; York v. Farmers' Bank, 105 Mo. App. 127, 79 S. W. 968 (1904) (constructive trust held to arise); Pile v. Bank of Flemington, 187 Mo. App. 61, 173 S. W. 50 (1914) ; Ballard y. First National Bank of Bolivar, 195 S. W. 559 (Mo. 1917); Armstrong v. First National Bank of Boliver, 195 S. W. 562 (Mo. 1917); State cx rel. Roberts v. Trimble, 316 Mo. 354, 289 S. W. 796 (1926) ; First National Bank of Littlefield v. Neel, 10 S. W. (2d) 408 (Tex. 1928) ; Thomas v. Farmers' Nat. Bank of Ludlow, 217 S. W. 860 (Mo. 1920), 236 S. W. 376 (Mo. 1922). Accord: Canadian Bank v. McCrea, 106 IIl. 281 (1882); People's State Bank of Michigan Valley v. Brown, 80 Kan. 520, 103 Pac. 102 (1909); Chadd v. Byers State Bank, 111 Kan. 279, 206 Pac. 880 (1922); Crocker State Bank v. White, 226 S. W. 972 (Mo. 1920); First National Bank of Byars v. Griffin \& Griffin, 31. Okla. 382, 120 Pac. 595 (1912); Continental Bank \& Trust Co. v. Hartman, 129 S. W. 179 (Tex. 1910); see Manget v. National City Bank, 168 Ga. $876,882,149$ S. E. 213 , 216 (1929) (statute mentioned is only declarative of com: mon law rule; see note 23, infra); cf. Wright v. Mississippi Valley Trust Co., 144 Mo. App. 640,129 S. W. 407 (1910); Lewis v. James Mcirahon \& Co., 307 Mo. 552, 271 S. W. 779 (1925). But cf. Perry v. Bank of Smithfield, 131 N. C. 117, 42 S. E. 551 (1902).

23. If the defendant is not a bona fide purchaser for value, the vendor universally prevails. Harbert v. Ft. Smith Canning Company, 134 Kan. 240, 5.P. (2d) 849 (1931); 
theory makes the plaintiff's right depend neither on the bank's promise to the dealer ${ }^{25}$ nor on the fact that the plaintiff is the payee or holder of a check wrongfully dishonored by the defendant. ${ }^{20}$ In this view, the plaintiff might recover against the depositee bank even if the check he received in payment were drawn on and dishonored by a different bank.

Where recovery is allowed on this theory, the courts frequently engage in a discussion of whether the bank had notice of the payee's rights, much as they do in actions brought against a purchaser of the goods where they are confronted with the split of authority ${ }^{2 \pi}$ as to whether recovery can be had against an innocent purchaser. The bank is usually charged with such notice, apparently on the ground that it knew that the dealer had paid the plaintiff for the merchandise in question by check. But it seems doubtful if this knowledge alone should be sufficient, since it can well be argued that in order to charge the bank with notice that title to the goods did not pass, the evidence

ALott v. Nelson, 96 Okla. 117, 220 Pac. 617 (1923); see Notes (1924) 31 A. L. R. 578, (1928) 54 A. L. R. 526 (concluding that the rule extends no further). But there is authority that the doctrine may be invoked even as against innocent subvendees. National Bank of Commerce v. Chicago, B. \& N. R. Co., 44 Mfinn. 224, 46 N. W. 342 (1S90); Barksdale v. Banks, 206 Ala. 569, 90 So. 913 (1921); Clark v. Hamilton Diamond Company, 209 Cal. 1, 284 Pac. 915 (1930); Johnson v. Iankovetz, 57 Ore. 24, 102 Pac. 799 (1909), 110 Pac 398 (1910); see 1 Willistors, SAles (2d ed. 1924) s22; VOLD, SALES (1931) 174.

In Georgia the rule is statutory as to the sale of certain agricultural products by planters or commission houses. GA. CoDE (1933) $\$ \$ 20-1004$, 96-110.

24. South San Francisco Packing and Provision Co. v. Jacobsen, $1 \$ 3$ Cal. 131, 190 Pac. 628 (1920) ; People's State Bank of Michigan Valley v. Brown, S0 Kan. 520, 103 Pac. 102 (1909) ; Wright v. Mississippi Valley Trust Co., 144 Mfo. App. 640, 129 S. W. 407 (1910) ; Miorehouse v. Keyport Auto Sales Co., 118 N. J. Eq. 368, 179 Atl. 279 (1935) ; Continental Bank and Trust Co. v. Hartman, 129 S. W. 179 (Tex 1910); sce Note (1907) 13 L.R.A. (N.S.) 697, 705. The vendor has been consistently allowed recovery against the purchaser's trustee in bankruptcy. In re Tracy, 185 Fed. 844 (S. D. N. Y. 1911) ; In re Perpall, 256 Fed. 758 (C. C. A. 2d, 1919); Miarion Afachine Foundry and Supply Co. v. Girand, 285 Fed. 160 (C. C. A. 5th, 1922); In re Broomhall, Killough \& Co., 47 F. (2d) 948 (S.D.N.Y. 1930); Manufacturers Finance Co. v. Armstrong, 7S F. (2d) 289 (C. C. A. 4th, 1935); see Colyirer, Bamriruptcr: (3d ed. 1934) 1222; BLACK, BANRRUTTCY (2d ed. 1930) 466.

25. See State $e x$ rel. Scott v. Trimble, 289 S. W. 796, 802 (Mo. 1926). In John S. Hale \& Co. v. Beley Cotton Co., 154 Tenn. 689, 290 S. W. 994 (1927), the payce recovered although there apparently was no unconventional agreement between the dealer and the bank.

Since the bank may also be liable to the drawer, this theory in fact renders it doubly liable. It can be argued, however, that this does not conflict with the purpose of $\$ 159$ of the Negotiable Instruments $\mathrm{Law}$, because liability to the payce is in no way predicated on the ground that the bank wrongfully dishonored the check.

26. It would seem logical that a bank in such a case would be obliged to ignore a stop-payment order by the drawer. Cf. Mroravek v. First Nat. Banl: of Jewell City, 119 Kan. 84, SS, 237 Pac. 921, 923 (1925).

27. Note 23, stipra. 
should warrant a finding that the bank knew not only that payment was to be made by check, but also that the parties contemplated a cash sale. ${ }^{28}$ Another view of the bank's position would often enable the courts to dispense entirely with the troublesome problem ${ }^{20}$ of notice. In the cases under discussion, the bank's status seems to be either that of an unsecured or a secured creditor of the dealer rather than a purchaser of the goods. The bank would clearly be an unsecured creditor of the dealer where it merely received the resale proceeds or a draft therefor without a bill of lading; ${ }^{30}$ and although where the bank discounts a draft and takes a bill of lading, the nature of its interest is not entirely clear, the parties probably intend it to have merely a security interest and not complete ownership. ${ }^{31}$ At least when the bank is an unsecured creditor, its knowledge of the transaction between the payee and the dealer apparently should be unimportant, since in actions by the vendor against other types of unsecured creditors of the vendee, the question of notice is ignored by the courts, ${ }^{32}$ the vendor recovering simply on the ground that the creditor can acquire no greater interest than his debtor. ${ }^{33}$ Notice might be considered important, however, in the case of secured creditors, where it would be easier to argue that the creditor had relied on the vendee's apparent ownership of the specific goods. ${ }^{34}$

28. See Vord, SAles (1931) 176; Perry v. Bank of Smithfield, 131 N. C. 117, 120, 42 S. E. 551, 552 (1902); cf. First National Bank of Chicago v. Pettit \& Smith, 41 III. 492 (1866) ; 5 MIICHIE, op. cit. sulpra note 1, 379 ("The knowledge on the part of a bank that checks have been drawn does not render it obligatory on the part of a banls to retain the deposit to meet them").

29. In Thomas v. Farmers' National Bank of Ludlow, 217 S. W. 860 (MLo. 1920), 236 S. W. 376 (Mo. 1922), the question of notice was still unsettled after two trials.

30. Where it discounts the draft, however, the bank might be said to be a purchaser of the paper. See Notes (1921) 11 A. L. R. 1046, (1930) 68 A. L. R. 727, (1935) 99 A.L. R. 488; 5 MichIE, op. cit. sitpra note 1, 59 et seq.; 2 Míorse, op. cit. sttpra note $1, \S 586$. For a valuable discussion of the problems involved, concluding that such a description of the bank's status is inaccurate, see Turner, Deposits of Demand Paper as "Purchases" (1928) 37 Yale I. J. 874.

31. Leonhardt \& Co. v. Small \& Co., 117 Tenn. 153, 96 S. W. 1051 (1906); see Comment (1926) 26 Coc. L. Rev. 63. But cf. Weed v. Boston \& Maine R. R., 124 Me. 336, 128 Atl. 696 (1925) (holding that the seller could not maintain an action against the railroad for the loss of the goods shipped because the bank had title to the goods).

32. See cases cited note 24 , supra.

33. See South San Francisco Packing and Provision Co. v. Jacobsen, 183 Cal. 131, 136, 190 Pac. 628, 630 (1920).

34. Where the original vendor has been denied recovery against innocent subvendees, the theory ordinarily invoked is that the subvendee had a right to rely on his immediate vendor's apparent ownership. See cases cited note 23, sitpra. The same argument might be advanced in favor of an innocent creditor who had relied on his debtor's apparent ownership. Reliance could easily be shown in the case of secured creditors. $C f$. (1935) 35 Cor. L. Rev. 1305. But cf. Federal Bldg. Co. v. Ford Motor Co., 199 N. E. 163 (Ind., 1936).

It has been suggested that the vendor in a conditional sale may be estopped to recover against the creditors of his vendee. See 1 Whliston, Sales (2d ed. 1924) 
But even if the question of notice is considered immaterial, this explanation of the cases is vulnerable to attack. The underlying rule that in a cash sale title remains in the seller until the check is paid has been sharply assailed on the ground that an unreserved conveyance of dominion over the goods by the vendor justifies a conclusion that he intends to pass title. ${ }^{35}$ This would seem particularly cogent in the instant circumstances where the vendor must usually realize that the vendee is purchaising only for immediate resale. ${ }^{35}$

The somewhat extraordinary group of cases under discussion are of twofold significance. In the first place, they indicate that the disfavored overdraft agreement is not so rare an occurrence in American banking as is sometimes supposed. ${ }^{37}$ In addition, they represent a class of cases in which the courts have consistently evaded Section 189 of the Negotiable Instruments Law and have imposed on the bank a duty similar to that which it would owe to the seller of goods who had relied on a commercial letter of credit issued by the bank in favor of the buyer. ${ }^{38}$ The uniformity with which re-

$\$ 326$. But apparently something more than mere possession of the goods by the vendee is necessary, such as an authorization to resell, or the vendee's possession of some indicia of title. See WirLIston, sicpra $\$ 329$.

35. See King v. Adams, 265 Fed. 9, 11 (C. C. A. Sth, 1920); Johnson-Brinlaman Commission Co. v. Central Bank of Kansas City, 116 MLo. 55S, 572, 22 S. W. \$13, 816 (1S93); Goodwin v. Bear, 122 Wash. 49, 51, 209 Pac. 10 SO (1922); 1 WILLIsror, SnLes (2d. ed. 1924) $\$ \$ 346 a, 346 b ;$ Vold, Sales (1931) 175.

36. In Parma v. First National Bank of Cameron, 37 S. W. (2d) 274, 276 (Te:: 1931), it was stated that such action on the part of the seller conclusively indicated an intent to pass title and so resulted in a waiver of his right to reclaim the property from innocent subvendees; $c f$. First National Bank of Chicago v. Pettit \& Smith, 41 Ill. 492 (1866). But cf. Ballard v. First National Bank of Bolivar, 195 S. W. 559, 561 (Mio. 1917).

37. That unsecured commercial overdraft arrangements are unusual in the United States, see Aloore, Coarurerctal Bank Credr I (unpublished manuscript, Yale Law Library 1936) 64; TrANT, BANK Adarnistratros (1931) 216. That they are generally frowned upon in this country as an unwise banking practice, see WESTERrIELD, BAstrurG

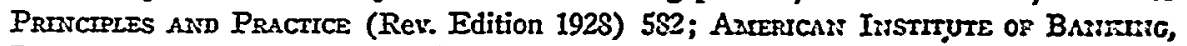

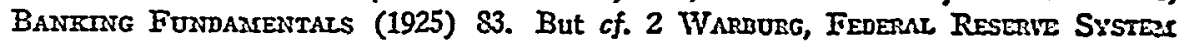
(1930) 469. They are, however, a familiar practice in England. See U. S. BUnEnU of

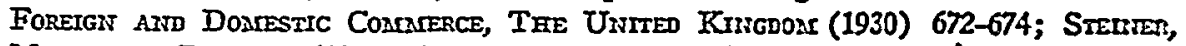
MIONEY AND BANRKNGG (1933)-209; 1100RE, stipra, at 65-103. Insofar as can be discerned from the reported opinions the arrangements in the principal cases seem distinguishable from the normal English type in that they are apparently "requirement contracts" not limited to a definite maximum figure.

3S. Cf. Nelson v. First National Bank of Chicago, 4S Ill. 36 (186S). For cases involving actual documentary letters of credit, see American Steel Co. v. Irving Nat. Bank, 266 Fed. 41 (C.C.A. 2d, 1920), 277 Fed. 1016 (C.C.A. 2d, 1921), ccrt. dcn., $25 S$ U.S. 617 (1922) ; De Sousa v. Crocker First Nat. Bank of San Francisco, 23 F. (2d) 118 (N. D. Cal. 1927); Note (192S) 53 A. L. R. 57. See generally, Miead, Nature of Rights and Obligations Created by Doctunentary Letters of Credit in Whro, Asrerucurs

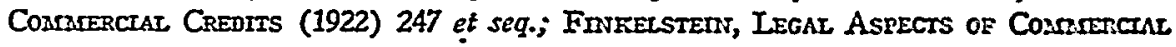


covery has been allowed, and the variety of rationalizations which have been employed, ${ }^{39}$ suggest that the courts have been motivated by considerations which the opinions do not ordinarily reveal. The courts may feel that the bank, by sanctioning this method of maintaining a checking account, has encouraged the dealer to issue checks before depositing funds with which to meet them, and is therefore to some extent responsible for the payee's predicament, which is normally complicated by the dealer's insolvency. 10 Furthermore, perhaps of even greater influence may be the fact that the plaintiff is ordinarily the original producer of the commodity involved, and a bias in his favor is part of a familiar social attitude. ${ }^{41}$

Letrers of Credit (1930) 150 et seq.; McCurdy, Combnercial Letters of Credit (1922) 35 Harv. L. Rev. 539, 563; McCurdy, The Right. of the Beneficiary under a Contmercial Letter of Credit (1924) 37 HARv. L. REv. 323. That a letter of credit may be general, see American Steel Co. v. Irving Nat. Bank, supra, at 43; Finkelstein, supra, at 94. The most favored theory on which recovery is allowed the seller under a commercial. letter of credit is that a direct contract arises between him and the bank, the consideration moving from the buyer. See Mead, supra, at 251; MIcCurdy, supra, 37 Hanv. L. REv. at 337.

39. Fraud has occasionally been invoked as a basis for relief. Gillen' v. Wakefield State Bank, 246 Mich. 158, 224 N. W. 761 (1929); of. Singer v. Citizens' Bank of Headrick, 79 Okla. 267, 269, 193 Pac. 41, 43 (1920).

Where the circumstances were somewhat analogous, the courts have sometimes used other rationales. Thus, it has been held that although an unaccepted check of itself is not an assignment, its issuance coupled with other facts might create one. Conn v. San Antonio National Bank, 249 S. W. 1045 (Tex. 1923) ("assignment pro tanto" held to result from bank telegram "good today"); Guaranty State Bank v. Sumner, 278 S. W. 459 (Tex. 1925) (bank's oral assurance to cattle vendor that check would be paid worked an assignment); cf. People's Nat. Bank v. Swift, 134 Tenn. 175, 183 S. W. 725 (1916) (delay in returning check to payee held to be acceptance under $\$ 137$ of the Negotiable Instruments Law). But $c f$. Bank of Magazine v. Friddle, 179 Ark. 53, 14 S. W. (2d) 238 (1929).

An equitable assignment has been held to result where the drawee is aware that the drawer has designated to the payee the funds from which the check would be paid. Boyle v. Vivian State Bank, 55 S. D. 441, 226 N. W. 579 (1929); First National Bank v. Rogers-Amundson-Flynn Co., 151 Minn. 243, 186 N. W. 575 (1922) (suit by bank against dealer's consignee) ; cf. Nelson v. Conroy Savings Bank, 196 Iowa 391, 194 N. W. 204 (1923). These cases rest ultimately on language employed in Fourth Street Bank v. Yardiey, 165 U. S. 634 , at 644 (1896).

For a discussion of the possibility that special circumstances may create a constructive acceptance by estoppel, see Feezer, Acceptance of Bills of Exchange by Conduct (1927) 12 Mrinv. L. Rev. 129. See generally, ArGler, supra note 3, at 862; Comment (1928) 37 Yale L. J. 626; (1930) 39 YaLe L. J. 744; (1930) 8 N. C. L. KeV. 201; 2 WiLliston, Contracts (Rev. ed. 1936) $\$ \$ 425,426$.

40. See Pascoe v. Franklin County State Bank, 217 Iowa 205, 211, 251 N. W. 63, 66 (1933). Cf. Gillen v. Wakefield State Bank, 246 Mich. 158, 224 N. W. 761 (1929).

41. In Georgia special statutory protection is accorded planters and their commission houses. See note 23 , supra. 